\title{
MONEY LAUNDERING AS A FORM OF ECONOMIC CRIME IN THE ROLE OF FINANCING TERRORISM
}

\author{
UDC 343.9.024:327.88
}

\section{Borko Milošević}

\author{
Academy for National Security, Belgrade, Republic of Serbia
}

\begin{abstract}
In terms of the dynamic of the international economic environment, economic organized crime has become a threat to national and international security. Political power acquired through illegal accumulation of economic power is rapidly expanding across all spheres of society. Money laundering and terrorist financing are global problems which have harmful effects on national economic, political, security and social structures. Terrorism cannot survive without financial means, which are very important for the terrorist organization. Therefore, the successful fight against terrorism and terrorist financing rests on adequate understanding of the concepts of money laundering and terrorism, and their interrelationships. In this paper, the author identifies money laundering as one of the main forms of economic crime. Using descriptive and historical method, an attempt was made to explain the scientific concept of money laundering and its importance to society and the state. In addition, the author explained the concept of terrorism and its financing and tried to find common characteristics of these seemingly incompatible phenomena, in order to emphasize the dangers of harmful consequences that could arise from inadequate opposition by the state and society.
\end{abstract}

Key words: money laundering, terrorism, financing terrorism, "Hawala" system

\section{INTRODUCTION}

Organized criminal is one of the biggest Post-Cold War era transnational security problems. It can be considered as a serious threat to legal state, democracy, the rule of law, international peace and stability. The political priority of solving this problem is increasing in a growing number of states. Although there are opinions that the problem has to be solved primarily or exclusively from the aspect of national security and protection of national interests, values of human and international security certainly shall not be neglected either (Piccarelli, 2008: 462-464). The negative effects of organized criminal are

Received December $20^{\text {th }}, 2016 /$ Accepted December $27^{\text {th }}, 2016$

Corresponding author: Borko Milošević

Academy for National Security, Kraljice Ane bb, 11000 Belgrade, Republic of Serbia

E-mail: borkolaw@gmail.com 
manifested in at least three dimensions of state and social life: human dimension, economic dimension and security dimension (in a narrow sense) (Mijalković, 2005: 247-248).

Human dimension is connected to the violation of human rights of many direct or indirect victims of organized-crime. Many countries have not conceived special strategies for the prevention and suppression of organized crime, i.e. for human rights protection of potential and actual victims, which ultimately results in primary, secondary and tertiary victimization.

Economic dimension refers to the damage that organized crime causes to an individual, society, state and international community, which further deepens the adverse factors of economic transition that are the cause and condition of its creation.

Security dimension refers to slowing down the process of democratization in the socalled transition societies, undermining of democratic institutions and the rule of law, as well as creating numerous socio-economic problems. Weak and corrupted state institutions and inappropriate statutory legislation prevent governments to successfully fight against this problem, all of which internally and externally endangers the national security.

Penetration of organized crime has been recorded in economic activities involving the commission of economic crime, featuring elements of organized crime. The penetration of organized crime in legal economic flows enables obtaining knowledge about and abuse of modern business practices, contributes to the sophistication of illicit operations and expansion of influence spheres. This confirms the aforementioned thesis that economic power of organized crime is used for gaining political power. In this way, economic crime becomes a threat for the national and international security. "Dirty money" enables criminal organizations to engage in criminal activities and corruption of public authorities. Thus, the criminal activity as well as the nature, origin and the existence of illegal proceeds remain hidden, which enables an uninterrupted use of illegal profits (Mijalković, 2011: 210).

As a specific form of organized criminal, money laundering threatens all significant values of a society. It encourages drug dealers, terrorists, arms smugglers, corrupt public officials and others to engage in and expand their criminal activities. The consequences of money laundering are numerous: undermining the stability, transparency and efficiency of the financial system of a country; decline of legal transactions in the private sector; impact on exchange rates and interest rates; economic disorders and instability; reduction in government revenues and weakening of economy policy control; endangering the reform program and privatization; decline in country reputation; reduction of investments; loss of state reputation and endangering the national security. Money laundering is the process that takes place according to the rules but the essential feature of this process is that it is extremely changeable and adaptable to the circumstances and conditions in which it takes place.

\section{MONEY LAUNDERING}

\subsection{Concept}

Economic crime is a complex criminological phenomenon which appeared in the contemporary society with the development of economy. This type of crime involves a group of criminal offences against social property and economic systems (Konstantinović-Vilić, Nikolić Ristanović, Kostić, 2012). In addition, economic accompanies all social changes and changed economic conditions, successfully using them to achieve illegal material gain; in that course, it demonstrates considerable economic resilience and perseverance towards 
measures for combating crime. One of the most important characteristics of economic crime is dynamism, adaptability to change, and its covert nature, all of which makes the detection and proving of these criminal offences much more difficult.

The concept of money laundering was originally developed in the United States in the $20^{\text {th }}$ century. In legal theory, there are several conceptions on money laundering. Thus, money laundering can be defined as a process in which the income, which is reasonably suspected to have been acquired through criminal activity, has been transferred, exchanged or blended with the legal funds in order to conceal its true nature, origin, use, movement or ownership. This process is aimed at making the obtained "illegal" funds appear legal (Richards, 1999: 44). In explaining the phenomenon of money laundering, an interesting interpretation was provided by McClean: "From the standpoint of criminals, it is pointless to pursue profit by a criminal activity if that profit cannot be used... Exploitation of the income is not as simple as it can be thought. A part of the proceeds of crime will remain as equity to fund future criminal acts, but a smart criminal will seek to use the rest for something else... If criminals want to do it in a way which will not involve too much risk of discovery, money acquired through a criminal activity has to "be washed" to acquire the status of impeccable origin" (McClean 2002: 261). According to another definitions, money laundering is a specific process of moving illicit gains, which lasts longer or shorter, in order to obtain, through the cycle of transformation, ostensibly legitimate gains in the end (Radonjić, 2015).

According to the National Strategy for combating money laundering and terrorist financing, there are three phases: investment phase, concealment phase, and integration phase.

\section{a) Investment phase}

The start of this phase involves severing all connections of money and incriminating actions by which the money has been acquired, and its insertion into the financial system. Once the "dirty money" is mixed with legitimate financial resources, it is much harder to detect a crime. This phase is most frequently put into practice by: effecting payments of money of dubious origin, under the guise of ordinary business transactions and legally generated revenues; establishing "ghost" economic entities to whose accounts cash payments are made; depositing a certain amount of cash funds to these accounts (in amounts that do not raise suspicion by bank employees and call for being traced); buying companies that are in debt, etc. Illegally obtained money can be transferred across state borders and deposited in bank accounts in countries that do not have strict control over cash movement. Later, that money is often used to purchase goods of high value. The "investment" phase is a key stage for prevention of money laundering because it is most adequate for proving the origin of money gained by criminal activity and, thus, the riskiest.

\section{b) Concealment phase}

At this stage, the aim of the operation is to enter the funds into a legal, economic and financial system by carrying out as many transactions as possible between the phase of making cash deposits and the integration phase. It takes place in the form of opening bank accounts (for no commercial purposes) in a number of different countries which have electronic money transfer services; due to a vast number of daily transactions, a high degree of anonymity and the speed of electronic money transfer provide the extraordinary 
advantage of concealing the money origin. At this stage, the perpetrators use shell corporations, which also have and operate by using legal funds (Radonjić, 2015: 34). Thus, "dirty" money enters a legal financial system and is then transferred from one account to another through multiple transactions, by means of which the "money launderers" try to conceal the relationship between the money and the committed crime. The "money launderers" often establish business entities abroad issue false or considerably augmented invoices for the benefit of other companies concerning business which has not been done at all or which is disproportionate in terms of quality and quantity of goods or liabilities.

\section{c) Integration phase}

In the integration phase, "dirty" money is placed into a legal economic and financial activity in such a way that it is impossible to disclose. The money launderers use a complex web of international transactions, which makes tracing the original source of funds impossible; the activities in this phase include: early repayment of loans, payment of counterfeit bills, privatization, purchase of goods such as real estate, precious stones, cars, boats, and the like. Currently, a very popular method of integration is the investment in companies that are facing difficulties, whereby companies continue to operate normally using that money as its capital while the "money launderers" receive interest and dividends from investment resources as a legal revenue (Radonjić, 2015: 35).

\subsection{Definition and positive-law framework of money laundering}

Money laundering entails activities aimed at the legalization of money gained from criminal activities. Participants in money laundering use a wide range of different transactions to cover the real origin of money and make it a legal means of transactions on the money market, which ultimately enables them to use it in regular business relations where they invest their capital" (Kulić, 2001: 39). According to the definition provided by the Bank of England, money laundering is the process by which criminals attempt to conceal the true origin and ownership of the proceeds of their criminal activities. If done successfully, it allows them to maintain control over those proceeds and ultimately provides a legitimate cover for their source of income. ${ }^{1}$ The definition of money laundering provided by the European Monetary Institute (EMI) in Luxembourg ${ }^{2}$ reads as follows:"Money laundering is any work (especially concealment, masking, acquisition, possession, use, investment, movement, storage or transferring assets) which the law marks as the status of specific criminal activities, specifically related to the criminal offense and the actions set out in the law and refers to profits that is a means any economic advantage from other criminal actions."

The Republic of Serbia is one of a hundred countries that signed and ratified the United Nations Convention against Illicit Trafficking in Narcotic Drugs and Psychotropic Substances, adopted in Vienna in December 1988 (the Vienna Convention) ${ }^{3}$, which includes the first definition of the criminal offense of money laundering. The definition is related

\footnotetext{
${ }^{1}$ Bank of England, Quarterly Bulletin: November 1992, Countering money laundering, http://www.bankofengland. co.uk/archive/documents/historicpubs/qb/1992/qb92q4418426.pdf

${ }^{2}$ European Monetary Institute (EMI), Luxemburg; http://www.ecb.europa.eu

${ }^{3}$ United Nations Convention against Illicit Traffic in Narcotic Drugs and Psychotropic Substances (the Vienna Convention, 1988); http://www.incb.org/e/conv/1988/
} 
and limited only to income and property acquired by the commission of criminal offenses related to narcotic drugs and psychotropic substances. Thus, money laundering implies:

- The conversion or transfer of property with the knowledge that such property is the result of the commission of one or more criminal offenses related to drug trafficking or on the basis of participation in such a criminal offense or criminal offenses, for the purpose of concealing the illicit origin of the property or assisting any person who is involved in the commission of such an offense to avoid the legal consequences of these activities;

- The concealment or disguise of the true nature, source, location, disposition, movement or ownership of rights or property with the knowledge that they are the result of one or more criminal acts related to drugs or takes part in one or more such offenses. ${ }^{4}$

According to the Palermo Convention (2000) $)^{5}$, characteristics of money laundering are defined in the same way as in the Vienna Convention, except for the fact that in the Palermo Convention the illegal activities are related not only to narcotics but also to terrorism, human trafficking, weapons and criminal acts that result in huge profits. A predicate criminal offence implies any kind of criminal offense committed for the purpose of acquiring illicit profit, which may be the subject matter of the criminal offence defined in Article 6 of the Convention (Radonjić, 2015: 26). The difference between the Vienna Convention and the Palermo Convention lies in the understanding of the predicate offense. Namely, twenty years after the adoption of the Vienna Convention, the Palermo Convention was no longer limited to illegal activities related to narcotics; it now included a list of criminal offences that provide huge profits, such as: terrorism, human trafficking, trafficking in weapons, and others. The CoE Convention on Laundering, Search, Seizure and Confiscation of the Proceeds from Crime, which was made in Strasbourg in1990, imposed an obligation on State Parties to adopt a very broad definition of predicate offenses, which would cover a large of criminal acts involving illegally acquired huge funds or proceeds of crime intended for insertion into legal economic flows, financing of terrorism, and the like. The 2005 Convention on Laundering, Search, Seizure and Confiscation of Proceeds from Crime and on the Financing of Terrorism (the Warsaw Convention) ${ }^{6}$ updated the Strasbourg Convention by imposing an obligation on the State Parties to adopt legal and other possible measures to criminalize such offenses by envisaging them as intentional pre-meditated criminal acts.

Under the Criminal Code of the Republic of Serbia (Article $231 \mathrm{CC})^{7}$, money laundering is defined as a criminal act committed by a person who: converts or transfers property, knowing that such property constitutes proceeds of crime, with intent to conceal or disguise illegal origin of the property, or a person who conceals or misrepresents facts about the property, knowing that such property originates from a criminal offence; or a person who acquires, keeps or uses such property knowing, at the time of receipt, that such property is derived from a criminal offense. The prescribed punishment for the commission of this criminal offence is a term of imprisonment ranging from six months to five years and a

\footnotetext{
${ }^{4}$ The Vienna Convention (1988), Art 3 par. 1 , items b (1) and b(2).

${ }^{5}$ UN Convention against Transnational Organized Crime (the Palermo Convention, 2000), http://www.undcp. org/adhoc/palermo/convmain.html

${ }^{6}$ The Convention was adopted in Warsaw by the Committee of Ministers of the Council of Europe on May 3, 2005.

${ }^{7}$ Criminal Code of the Republic of Serbia (Article 231), Official Gazette of RS, No. 85/2005, 88/2005-corr., 107/2005-corr., 72/2009, 111/2009, 121/2012, 104/2013 and 108/2014
} 
fine (Art. 231 par.1). A more severe form of this criminal act will exist if the amount of money or property exceeds one million five hundred thousand dinars, in which case the offender shall be punished by a term of imprisonment ranging from one to ten years and a fine (Art. 231 par. 2). In case the offence involves the use of assets that the perpetrator himself acquired through the commission of the criminal offence, the offender shall be issued a penalty prescribed in paragraphs 1 and 2, and a fine (Art. 231 par. 3). If the first two forms of this criminal offence are committed in a group, the offenders shall be punished by a term of imprisonment ranging from two to twelve years, and a fine (Art. 231 par. 4). Moreover, a person who commits the first two forms of this criminal offence, and could have been aware and should have known that money or property represents the proceeds of crime, shall be punished by a term of imprisonment of up to three years (Art. 231 par. 5). The responsible person, who commits the offence specified in paragraphs 1,2 and 5 of this Article, shall be punished by imposing the penalty prescribed for that offense, if the person was aware, or could have known, and was obliged to know that the money or property are the proceeds of crime (Art. 231 par. 6). The money and property acquired by the commission of this criminal offense shall be seized (Art. 231 par. 7).

According to the Act on the Prevention of Money Laundering, ${ }^{8}$ money laundering implies: the conversion or transfer of property, knowing that it is derived from a criminal offense, in order to conceal or disguise its illicit origin; concealment or misrepresentation of facts in relation to the property, knowing that such a property is derived from a criminal offense; acquisition, possession or use of the property, knowing, at the time of receipt, that it is derived from a criminal offense; concealing illegally acquired social or state assets, and social or state capital, in the process of ownership transformation of enterprises and other legal entities. The term assets implies movable and immovable property, money, rights, securities and other documents evidencing the right of ownership and other rights. The term money refers to cash, foreign cash, deposits in accounts (in RSD and FX), and other means of payment (Mijalković, Bajagić, 2012: 532).

The most comprehensive definition of the term money laundering is as follows: "the process through which the benefits, which are reasonably believed to have been proceeds from a criminal activity, are transported, transferred, transformed, converted or incorporated into legal financial flows in order to conceal their origin, source, movement or ownership, to allow these assets to emerge as legitimate, and to enable the persons involved in criminal activities to avoid legal consequences of such illegal activities" (Taseva, 2003: 36).

\section{TERRORISM}

\subsection{Concept and definition}

All criminal acts are characterized by unlawfulness, social danger and harm to individuals and society, which puts them in the same category as negative social phenomena, i.e. crime. There is a vast number of criminal offences where violence is part of a criminal act, or part of the manner of its commission; regardless of the object of attack, they constitute violent crime. All forms of violence are characterized by the aggressiveness of the perpetrator to the victim. In terms of criminal offenses involving acts of violence, there is a special kind of violent crime which may be designated as political crime, aimed at accomplishing

\footnotetext{
${ }^{8}$ Act on the Prevention of Money Laundering ("Official Gazette of RS", No. 107/05, Art. 2 and 4)
} 
political goals. Political crime is closely linked to political relations in a society and it can be divided into through two groups of criminal offences. The first group consists of criminal acts against the state or the government (such as: betrayal, espionage, armed insurgency, terrorism); the second group of criminal acts includes criminal acts committed by the government against political opponents and for the sake of unlawful enrichment.

In its common usage, the word terrorism has a connotation of evil, indiscriminate violence, or brutality. Someone has been terrorized! Thus, labeling a group or an action as a terrorist group/action implies that the actor or action is immoral, wrong or contrary to obvious basic ethical principles that any reasonable human being might hold. However, the use of different terms (such as: freedom fighter, revolutionaries, rebels, resistance fighters, members of the democratic opposition, or national liberation soldiers) for the violence that may occur in their course of action implies that the group undertaking the violence is motivated by some greater good or higher moral principle (Lutz, Lutz, 2004: 8).

Today, terrorism is the most commonly mentioned political issue. There is no part of the world that has not been confronted with this phenomenon. While classical wars and armed conflicts (which were the hallmark of the $20^{\text {th }}$ century) are now generally considered to be part of history, at the end of the $20^{\text {th }}$ century and at the beginning of $21^{\text {st }}$ century, the society and the international community stated facing the phenomenon of political violence which has replaced the wars that we can find in history books. The growing phenomenon of political violence in various forms is an interesting topic for scientists endeavoring to tackle the definition of terrorism. In order to know what we are fighting against and how to fight it, we first have to know what it is (Simeunović, 2009: 6).

As a form of political violence, terrorism is a phenomenon that jeopardizes the fundamental moral values and brings into conflict not only the people and societies linked to terrorist activities but also their moral values, and through them, the overall personal and social life. In a broad sense, terrorism implies the use of violence or threat of violence for political reasons, in order to intimidate and break the resistance of those it is aimed at (Bajagić, 2011: 204). For a proper understanding of the concept of terrorism, it is necessary to pay attention to its basic elements: a) conscious and intentional use of violence or threat of violence; b) illegal and criminal act; c) political, religious and ethnic motivation; d) realization of political goals and sending a political message; e) criminal character, unpredictability, cruelty and ruthlessness; f) causing fear, panic and distrust; g) suffering of civilians and innocent victims; h) desire for publicity and media exposure (Stojanović, 2012: 343).

In literature, there is a collection of various attempts to define terrorism, terror, terrorist actions, terrorist acts (etc.), depending on the authors' standpoints when determining if an organization is a terrorist organization or a freedom fighter, i.e. if the specific acts are acts of terrorism or acts taken under the influence of ideology of liberation ${ }^{9}$ from oppressors ${ }^{10}$ (Pavković, 2007:49). Generally speaking, we can find explanation for each of these microconcepts, which are necessarily mentioned in the context of terrorism. In that context, research analysis proves that most authors agree that there is a difference between terrorism and terror.

\footnotetext{
${ }^{9}$ Ideology of liberation consists of a set of political attitudes and beliefs which promote actions and activities aimed at liberation from oppression and oppressors. Explanations of this term are often accompanied by the attitude that violence is justified as long as it is undertaken on behalf of the aforementioned ideology.

${ }^{10}$ The oppressor should be seen as a person, any member of the group that participates in the oppression. Franc Fanon defined them through race (as Europeans) and through social and political role of colonizers (see: Pavković, 2007:49).
} 
Terrorism is systematic and arbitrary violence against the same target, which is not necessarily caused by its guilt, but is purely an expression of one's free choice, one's great situational superiority and willingness to be violent (Simeunović, 2009: 23). Terror is a form of intensive and frightening violence that is done by someone in a dominant position, which does not necessarily include only the position of power but also the use of any currently superior position in human relations. But, as a political category, terror is violence used by some political power (Simeunović, 2009: 23). A terrorist act is a short-term but extremely violent act, the most pressing and the scariest segment of a terrorist activity. $A$ terrorist activity consists of a terrorist act and a number of other activities, starting from planning to commission of the act, and ending with propaganda and the mobilizing exploitation of its effects (Simeunović, 2009: 70).

While trying to determine the definition of terrorism, the authors encounter numerous difficulties arising from the fact that terrorism is characterized by dynamism, the variability of forms, double standards when defining terrorism, and the refusal of the state to define terrorism, which is caused by different political conflicting interests. Besides, terrorism is a covert activity, which has changed its meaning several times; the term itself is demonized, and terrorists are now involved even in legal political activities. Considering all the above, it seems that the most appropriate definition is the one from the second half of the 1980s, which is still largely applicable today: "Terrorism is a complex form of an organized group, and rarely individual or institutional violence, coated with daunting brachial-physical and psychological methods of political struggle, which are usually used during the political and economic crisis, and rarely during the period of economic and political stability in a society, to systematically achieve "big goals" in a way that is inappropriate for given conditions, primarily social situation and historical possibilities of those who use it as a political strategy. Terrorism involves the threat of force in the context of intense psychological and propaganda activities, kidnapping, blackmail, psychological and physical abuse, assassinations, sabotage, diversions, individual assassinations or mass political killings, which are aimed against the representatives of the system and innocent victims. As a form of individual, illegitimate, illegal and non-institutional violence, terrorism is always aimed against certain institutions in a society, that is, against the state" (Simeunović, 2009: 78).

\subsection{Financing of terrorism}

Financing of terrorism is a term used to describe the adaption, the provision and collection of financial transactions that can be directly linked to terrorists, terrorist activities and terrorist organizations. It is a simple concept expressed through financial support in any form of terrorist activities or those who encourage, plan or are involved in their implementation (Dimovski, Ilijevski, Babanoski, 2011:117). In most cases, terrorists are linked with organized crime, particularly, with money laundering as a form of economic crime. Although we can designate terrorism as a form of an organized crime, we must have in mind that their correlation is based on the level of connectedness. A relation between organized crime (more specifically, money laundering) and terrorism is instrumental but, in its essence, it is more often functional, because money laundering usually has a role in financing terrorism. The role of money laundering in financing terrorism is growing, and the fruits of this criminal act are picked by terrorist organizations, which use their resources to avoid criminal prosecution. Money laundering is performed in almost the same way as financing terrorism. Terrorist organizations are taking all necessary measures to hide the 
sources of their funding. However, we must take into account the fact that terrorist organizations and their actions do not use only illegal funds but also the legal ones, which are made available through the money laundering channels to the end-users: the organizers of terrorist activities and terrorists. The applied methods are directly dependent on the economic situation in the country, complexity of the market, the effectiveness of the law enforcement, international cooperation, and they differ from one country to another. This inevitably points to the connection of terrorism not only to organized crime (with which it is interlaced and is one of its manifestations) but also to transnational organized crime, for the ultimate purpose of securing the financial base for the organization and execution of terrorist activities. Namely, there are two main sources of financing terrorist activities:

- securing the financial support from certain countries or organizations; by obtaining the necessary financial resources, it is possible to create preconditions for establishing, organizing and functioning of terrorist organizations, groups and individuals; this way of financing is commonly referred to as the "sponsoring" financing of terrorism;

- direct, i.e. immediate securing of the funds, based on various legal and illegal activities which are performed by the members of the terrorist organizations.

One of the most common ways to transfer money, which is often associated with money laundering and financing terrorism is the "Hawala" system, which is actually an effective method of payment worldwide. "Hawala" is an alternative or parallel money transfer system, for which reason it is often called "underground banking". The word "Hawala" means trust. It is an alternative or parallel remittance system, which works outside the circle of banks and formal financial systems. "Hawala" is an ancient system of money transfer, which originated in South Asia and is now being used across the globe. Before the introduction of Western banking practices, this system was mainly developed in India.

The "Hawala" system operates easily and without many procedures; thereby, it avoids paying numerous fees and taxes, which makes it even more interesting for people who want to anonymously move their capital to another country. The "Hawala" system is set in motion when a person wishing to transfer funds from his country of origin to a foreign country (country of destination) addresses the "Hawala" dealer 1, who will take his money. Then, the person who wants to transfer the money goes to the country of destination and speak to the "Hawala" dealer 2, who will pay the amount that the person gave to the "Hawala" dealer 1 , minus the percentage that is charged by the dealer 1 . Thus, a person in the destination country provides funding to continue specific activities, while the debt between the "Hawala" dealers 1 and 2 shall be settled through the next transaction which is made in the opposite direction. Obviously, one of the key features of this system is trust, vested in the "Hawala" dealers, who are always honest in their dealings.

It is almost impossible not to notice that the "Hawala" system is ideal for transferring money from different countries to the country of destination, which is possible without knowing the origin of money, mainly used to finance terrorist activities and organizations. It is important to note that the "Hawala" system is often used for financing terrorism. Money that is gained from a committed criminal act (drug-trafficking, human trafficking, extortion, kidnapping, arms trafficking, etc.) comes from the "illegal" zone and is supplied by the "Hawala" dealer 1 . The system of trust that characterizes this mechanism implies ordering "Hawala" dealer 1 to order "Hawala" dealer 2 to pay money to the person who will use the money for recruitment, logistics, training and terrorist activities. The "Hawala" system has been made illegal in many countries, as it is deemed to be a form of money laundering and can be used to anonymously move wealth. As "Hawala" transactions are 
not routed through banks, they cannot be regulated by the government agencies. Thus, they have emerged as a major cause of concern. This network is being used extensively across the globe to circulate "black" money and to provide funds for terrorism, drug trafficking and other illegal activities.

\section{CONCLUSION}

Upon the provided analysis of money laundering, as a phenomenon of economic crime, we come to the conclusion that it is a complex activity, which usually requires good organization and patience during the implementation. In addition to the negative economic effects that this crime has on the country's economy and its markets, money laundering is often used for financing terrorism. It is an effective way of providing funds for the recruitment of members of terrorist organizations, their training and indoctrination, logistics, and commission of the planned terrorist activities. The financial sources that are provided for this purpose are very well hidden, which significantly complicates the process of counteracting and combating money laundering, terrorism and its financing.

On the other hand, the review of scientific literature on terrorism clearly shows that it is a very dangerous social phenomenon, involving illicit activities aimed at accomplishing political goals by targeting innocent victims and civilians. In this regard, counteracting all forms of terrorism is the main task of each country and the international community as a whole. Given the specific characteristics of money laundering and terrorism, terrorists often commence with the establishment of an organized criminal group (OCG), which is the first phase in the process of procuring funds for successful implementation of terrorist activities. By committing a wide range of serious crimes, the terrorists acquire substantial revenues, which have to be "laundered" by transferring the illegally obtained money into legal channels, whereupon it is used to further their primary objectives and to successfully carry out terrorist activities. This clearly indicates that terrorism cannot survive without funding. Terrorism is expensive and terrorist organizations easily adapt to various social and economic circumstances, and almost invariably find ways to finance their activities. The money gained by the commission of criminal activities, and subsequently "washed" through various parallel and alternative systems that exist worldwide, is very important for terrorist organizations. Therefore, successful fight against terrorism and terrorist financing must start from disclosing the financial sources of terrorism and counteracting money laundering. In this context, the decisions of international institutions and intergovernmental bodies should be duly implemented in the national legislation, which would provide conditions for the successful implementation of the adopted legislation. The process of overcoming these national security challenges calls for a higher degree of coordination and cooperation between the police, the banking system, customs, specialized bodies in charge of combating money laundering, foreign exchange inspectorates, financial police, market inspection and other security subjects. 


\section{REFERENCES}

1. Бајагић. М. (2011). Самоублички тероризам - савршено терористичко оружје (Suicide terrorism the perfect terrorist weapon), у: Супротстављање тероризму - међународни стандарди и правна регулатива, Висока школа унутрашњих послова, Бања Лука, 2011, стр. 204.

2. Bank of England, Quarterly Bulletin: November 1992, Countering money laundering, http://www.bankofengland.co.uk/archive/documents/historicpubs/qb/1992/qb92q4418426.pdf

3. Dimovski, Z., Ilijevski, I., Babanoski, K. (2011), Maze of financial assets in the process of money laundering in the function of financing terrorism, у: Супротстављање тероризму - међународни стандарди и правна регулатива, Висока школа унутрашњих послова, Бања Лука, стр. 117.

4. European Monetary Institute (EMI), Luxemburg. http://www.ecb.europa.eu ; accessed: 10.10.2016.

5. Konstantinović-Vilić, S., Nikolić-Ristanović, V., Kostić, M. (2012). Kriminologija (Criminology), Pravni fakultet u Nišu

6. Кулић, Мирко (2001). Прање новца, привредни криминал и корупција (Money laundering, economic crime and corruption), Институт за криминолошка и социолошка истраживања, Београд,

7. Krivični zakonik Republike Srbije (Criminal Code of the Republic of Serbia), Službeni glasnik RS, br 85/2005, 88/2005-ispr., 107/2005-ispr. 72/2009, 111/2009, 121/2012, 104/2013 i 108/2014

8. Lutz, J., Lutz, B. (2004). Global Terrorism, Routledge, London, 2004, p.8

9. McClean J.D. (2002). International cooperation in civil and criminal matters, Oxford, Oxford University Press, p. 261, taken from: В. Гилмор, „Прљави новац“, Плус, Београд, 2004, стр. 29.

10. Мијалковић, С. (2005). Трговина људима (Human trafficking), БеоСинг, Београд, стр. 247-248.

11. Мијалковић, С. (2011): Национална безбедност (National Security), Криминалистичко-полицијска академија, Београд, 2011, стр. 210

12. Мијалковић, С., Бајагић, М. (2012): Организовани криминал и тероризам (Organized crime and terrorism), Криминалистичко-полицијска академија, Београд, стр. 532

13. Nandan Narula, H.: What is Hawala? All you want to know about Hawala, accessed: 10.10.2016. http://www.n2moneymatters.com/2011/03/what-is-hawala-all-you-want-to-know.html

14. Pavković Aleksandar (2007). Terorizam kao instrument oslobođenja: stanovište ideologije oslobodjenja (Terrorism as an instrument of liberation: the standpoint ideology of liberation), Nova srpska politička misao, vol XIV, no, 102, Beograd, 2007, str. 49

15. Piccarelli, J. T. (2008): Transnational Organized Crime, Security Studies - An Introduction (ed. Williams, P.), Routledge, London-New York, p. 462-464

16. Радоњић, С. (2015). Укључивање нелегално стечене имовине у легане токове и њен утицајна економски развој и прерасподелу друштвеног богатства/докторска дисертација (The inclusion of illegal proceeds into legal channels and its influential economic development and redistribution of social wealth /doctoral thesis), Факултет за банкарство, осигурање и финансије, Универзитет Унион у Београду, Београд, 2015. str. 26, 34-35

17. Richards, J.R. (1999). Transnational Criminal Organisations, Cybercrime and Money Laundering, London, p.44

18. Симеуновић, Д. (2009). Тероризам. (Terrorism) .Београд, стр. 6, 23, 70, 78.

19. Stojanović Z. (2012). The offense of illicit enrichment: reasons for and against the introduction, published in the current criminal legislation (normative and practical aspects), Serbian Association for Criminal Law Theory and Practice and Intermex, Belgrade, p.343

20. Тасева, С. (2003). Перење пари, (Money Laundering), Дата Понс, Скопје, , стр. 36

21. UN Convention against Transnational Organized Crime (2000), http://www.undcp.org/adhoc/palermo/ convmain.html; accessed: 10.10.2016.

22. UN Convention against Illicit Traffic in Narcotic Drugs and Psychotropic Substances (1988), http://www.incb.org/e/conv/1988/; accessed: 10.10.2016

23. Zakon o sprečavanju pranja novca (Act on the Prevention of Money Laundering), Službeni glasnik RS, br $107 / 05$. 


\section{PRANJE NOVCA KAO OBLIK EKONOMSKOG KRIMINALITETA U ULOZI FINANSIRANJA TERORIZMA}

Ekonomski organizovani kriminal postaje pretnja nacionalnoj i međunarodnoj bezbednosti. $S$ njegovom internacionalizacijom, posledice su sve štetnije jer se brzo prilagođava uslovima međunarodnog ekonomskog okruženja. Nelegalno akumulirana ekonomska moć je osnova za sticanje neposredne i posredne političke moći. To je snažna poluga širenja uticaja u svim sferama društvenog života, naročito za ostvarivanje kriminalnih ciljeva infiltracijom u legalne ekonomske tokove. Pranje novca i finansiranje terorizma su globalni problemi koji imaju štetne efekte na nacionalne ekonomske, političke, bezbednosne i socijalne strukture. terorizam ne može da opstane bez finansijskih sredstava, koja su itekako važna za terorističke organizacije. S toga, uspešno suzbijanje terorizma i finansiranja terorizma, kreće od adekvatnog shvatanja pojmova pranja novca i terorzima i njihove međusobne veze.

Ključne reči: pranje novca, terorizam, finansiranje terorizma, "Havala " sistem 